\title{
PENERAPAN KONSEP DASAR PROSES KEPERAWATAN KELUARGA
}

\author{
Erta Iman Jelita Harefa/181101138 \\ ertahrf08@gmail.com
}

\begin{abstract}
Abstrak
Latar belakang: keperawatan keluarga yang merupakan pelayanan holistik yang menempatkan keluarga dan komponennya sebagai fokus pelayanan dan melibatkan anggota keluarga. Keluarga adalah salah satu aspek terpenting dari perawatan. Keluarga merupakan unit terkecil dalam masyarakat yang merupakan entry point dalam upaya mencapai kesehatan masyarakat secara optimal. Keluarga juga disebut sebagai sistem sosial karena terdiri dari individu-individu yang bergabung dan berinteraksi secara teratur antara satu dengan yang lain yang diwujudkan dengan adanya saling ketergantungan dan berhubungan untuk mencapai tujuan bersama. keluarga mempunyai anggota yang terdiri dari ayah, ibu dan anak atau sesama individu yang tinggal di rumah tangga tersebut.

Tujuan: Tujuan penulisan ini adalah untuk mengetahui dan memberi informasi tentang penerapan konsep dasar proses keperawatan keluarga.

Metode: Penulisan ini menggunakan metode literature review dengan pendekatan jurnal atau artike, buku dan e-book yang relevan dan akurat serta berfokus pada penerapan konsep dasar proses keperawatan keluarga. Adapun jurnal atau artikel dan $e$-book yang digunakan pada literature review adalah jurnal atau artikel dan e-book yang didapatkan dengan menggunakan Google Scholar, Portal Garuda, dan Jurnal Keperawatan Indonesia. Hasil: Berdasarkan hasil pencarian literatur didapatkan proses keperawatan yang terdiri dari pengkajian, diagnosa, perencanaan, implementasi, dan evaluasi keperawatan yang dimana sudah diterapkan dan dilaksanakan pada setiap keluhan atau kondisi yang dialami pasien/klien.

Pembahasan: Proses keperawatan merupakan suatu proses yang kompleks dan bersifat dinamis dengan menggunakan pendekatan yang sistematis pada keluarga dan anggota keluarga dengan metode ilmiah. Dalam hal ini sangat penting bagi seorang perawat yang akan melakukan suatu tindakan dengan menggunakan tahapan proses keperawatan.

Penutup: Dalam proses keperawatan pada keluarga sudah diterapkan dan dilaksanakan atau dilakukan. Penerapan proses keperawatan ini bukan hanya pada keluarga tapi pada setiap kondisi atau keluhan yang dialami oleh pasien/klien.
\end{abstract}

Kata kunci: penerapan, proses keperawatan, keluarga 


\section{LATAR BELAKANG}

Pelayanan keperawatan di masyarakat mempunyai sasaran dari tingkat individu, keluarga, kelompok, dan masyarakat. Pelayanan keperawatan di masyarakat bertujuan untuk mewujudkan masyarakat yang mandiri dalam pemeliharaan kesehatan. Dalam hal ini terdapat peran dan fungsi perawat dalam pelayanan keperawatan keluarga yang merupakan unsur penting dalam mewujudkan masyarakat yang sehat dan mandiri.

Keluarga adalah salah satu aspek terpenting dari perawatan. Keluarga merupakan unit terkecil dalam masyarakat yang merupakan entry point dalam upaya mencapai kesehatan masyarakat secara optimal. Keluarga juga disebut sebagai sistem sosial karena terdiri dari individu-individu yang bergabung dan berinteraksi secara teratur antara satu dengan yang lain yang diwujudkan dengan adanya saling ketergantungan dan berhubungan untuk mencapai tujuan bersama. Dalam hal ini, keluarga mempunyai anggota yang terdiri dari ayah, ibu dan anak atau sesama individu yang tinggal di rumah tangga tersebut (Andarmoyo, 2012).
Sehingga menjadi penting dalam membutuhkan pelayanan kesehatan seperti halnya individu yang dapat melakukan tugas sesuai perkembangannya. Tingkat kesehatan individu berkaitan dengan tingkat kesehatan keluarga begitu juga sebaliknya tingkat kesehatan keluarga dapat mempengaruhi derajat kesehatannya. Untuk itu jika terdapat disfungsi pada keluarga maka akan berdampak pada satu atau lebih anggota keluarga bahkan keseluruhan keluarga. Untuk itu diperlukan keperawatan keluarga yang merupakan pelayanan holistik yang menempatkan keluarga dan komponennya sebagai fokus pelayanan dan melibatkan anggota keluarga dalam tahap pengkajian, diagnosis keperawatan, perencanaan, pelaksanaan, dan evaluasi (Depkes RI, 2010).

Dalam hal ini diperlukan peran perawat untuk menunjang pelayanan keperawatan keluarga agar menjadi lebih baik dan dapat meningkatkan mutu pelayanan kesehatan yang ada di Indonesia. Pelayanan keperawatan keluarga merupakan salah satu area pelayanan keperawatan di masyarakat dengan memobilisasi sumber pelayanan kesehatan yang tersedia di keluarga dan 
sumber-sumber dari profesi lain (Depkes

RI, 2010).

Di Indonesia penerapan pelayanan kesehatan keluarga sudah dilakukan, dilaksanakan, dan diterapkan melalui dengan adanya Program Indonesia Sehat tetapi dalam melakukan peningkatan dalam pelayanan kesehatan keluarga masih kurang disebabkan karena kurangnya fasilitas alat-alat kesehatan yang digunakan untuk menunjang pelayanan kesehatan yang lebih baik. Dalam hal ini diperlukan dukungan pemerintah dan masyakarat dalam mewujudkan pelayanan kesehatan menjadi lebih baik dan lebih maju.

\section{TUJUAN}

Tujuan penulisan ini adalah untuk mengetahui dan memberi informasi tentang penerapan konsep dasar proses keperawatan keluarga.

\section{METODE}

Penulisan ini menggunakan metode literature review dengan pendekatan jurnal atau artike, buku dan e-book yang relevan dan akurat serta berfokus pada penerapan konsep dasar proses keperawatan keluarga. Adapun jurnal atau artikel dan $e$-book yang digunakan pada literature review adalah jurnal atau artikel dan e-book yang didapatkan dengan menggunakan Google Scholar, Portal Garuda, dan Jurnal Keperawatan Indonesia.

\section{HASIL}

Berdasarkan hasil pencarian literatur di dapatkan penerapan proses keperawatan keluarga sebagai berikut:

1. Pengkajian Keperawatan Keluarga Pengkajian merupakan tahapan dalam mengidentifikasi data-data, mengumpulkan informasi yang berkesinambungan secara terusmenerus terhadap keluarga yang dibina. Sumber data pengkajian melalui proses dari anamnesa (wawancara), pemeriksaan atau pengkajian fisik anggota keluarga dan pemeriksaan diagnostik maupun laboratorium serta dokumen rekam medik.

Dasar pemikiran dari pengkajian adalah suatu perbandingan, ukuran atau penilaian mengenai keadaan keluarga dengan menggunakan norma, nilai, prinsip, aturan, harapan, teori, dan konsep yang 
berkaitan dengan permasalahan (Dion \& Betan, 2015).

2. Diagnosa Keperawatan Keluarga Diagnosa keperawatan keluarga merupakan kesimpulan yang ditarik dari data yang dikumpulkan tentang keluarga. Diagnosa ini berfungsi sebagai alat untuk menggambarkan masalah keluarga yang dapat di tangani oleh perawat. Diagnosa keperawatan adalah penilaian klinik mengenai respons individu, keluarga, dan komunitas terhadap permasalahan kesehatan atau proses kehidupan yang aktual dan potensial. Diagnosa ini memberikan dasar untuk pemilihan intervensi keperawatan untuk mencapai hasil yang merupakan tanggungjawab perawat.

Diagnosa keperawatan keluarga merupakan hasil dari analisis data sari hasil pengkajian keluarga, yang dimana diagnosisnya diangkat berdasarkan masalahmasalah pada fungsi keluarga, struktur keluarga, dan lingkungan keluarga (Andarmoyo, 2012).
3. Perencanaan Keperawatan Keluarga

Dalam melakukan tindakan keperawatan maka perlu dilakukan perencanaan keperawatan. perencanaan keperawatan merupakan salah satu tahap dari proses keperawatan yang dimulai dari penentuan tujuan (khusus dan umum), penetapan standar dan kriteria serta menentukan perencanaan untuk mengatasi masalah keluarga. Adapun beberapa tingkat tujuan yang disusun dalam jangka pendek (khusus) dan jangka panjang (umum). Tingkatan ini digunakan untuk membedakan masalah yang dapat diselesaikan sendiri oleh keluarga. Tujuan khusus atau jangka pendek sifatnya spesifik, dapat di ukur, dapat dimotivasi atau memberi kepercayaan pada keluarga bahwa kemajuan sedang dalam proses dam membimbing keluarga ke arah tujuan jangka panjang atau umum. Tujuan jangka panjang atau umum merupakan tujuan akhir yang menyatakan maksud-maksud luas yang diharapkan oleh keluarga agar dapat tercapai. 
Selanjutnya terdapat penetapan

kriteria dan standar yang di dalamnya memuat komponen yaitu kognitif (pengetahuan), afektif (sikap), dan psikomotor (tindakan) (Dion \& Betan, 2015).

4. Implementasi

Keperawatan

Keluarga

Implementasi adalah pelaksanaan tindakan keperawatan yang sudah ditentukan sebelumnya. Adapun prinsip yang mendasar implementasi keperawatan keluarga antara lain:

a. Implementasi mengacu pada rencana perawatan yang dibuat.

b. Implementasi dilakukan dengan tetap memperhatikan prioritas masalah.

c. Kekuatan-kekuatan keluarga berupa finansial, motivasi, dan sumber-sumber pendukung lainnya jangan diabaikan.

d. Pendokumentasian implementasi keperawatan keluarga janganlah terlupakan dengan menyertakan tanda tangan petugas sebagai bentuk tanggung gugat dan tanggung jawab profesi

(Setiawati, 2008).

5. Evaluasi Keperawatan Keluarga Evaluasi merupakan tahapan terakhir dari proses keperawatan keluarga. Evaluasi bertujuan untuk mengetahui kemampuan keluarga dalam mencapai tujuan. Dalam evaluasi terdapat 2 jenis pelaksanaan asuhan keperawatan keluarga sebagai berikut:

a. Evaluasi Formatif

Evaluasi yang dilakukan sesaat setelah pelaksanaan tindakan keperawatan. penulisannya lebih dikenal dengan menggunakan format SOAP.

b. Evaluasi Sumatif

Evaluasi akhir apabila waktu perawatan sudah sesuai dengan perencanaan. Bila terdapat ketidaksesuaian dalam hasil yang dicapai, keseluruhan proses mulai dari pengkajian sampai dengan tindakan perlu ditinjau kembali.

Ada beberapa metode yang perlu dilaksanakan dalam melakukan evaluasi diantaranya adalah observasi langsung, wawancara, 
memeriksa laporan dan latihan stimulasi (Dion \& Betan, 2015).

\section{PEMBAHASAN}

Proses keperawatan keluarga akan relatif berbeda pada siapa yang akan menjadi fokus keperawatan. Perbedaan fokus tergantung konseptualisasi keluarga dari perawat tersebut. Jika dilihat keluarga sebagai latar belakang atau konteks dari pasien individu, maka anggota keluarga secara individu merupakan fokus dan proses keperawatan yang berorientasi secara individu. Dalam hal ini proses keperawatan merupakan suatu proses yang kompleks dan bersifat dinamis dengan menggunakan pendekatan yang sistematis pada keluarga dan anggota keluarga dengan metode ilmiah. Berdasarkan hasil yang didapat diatas maka proses keperawatan keluarga mengikuti pola keperawatan secara umum yang terdiri dari pengkajian, diagnosa, perencanaan, implementasi dan evaluasi (Andarmoyo, 2012).

Untuk itu dalam melakukan perawatan perlu dan harus melewati tahapan proses keperawatan dengan benar dan baik serta secara berurutan.

Selanjutnya dalam memberikan perawatan kesehatan pada keluarga pastinya akan terdapat hambatan baik dari keluarga maupun perawat. Hambatan dari keluarga terdiri dari pendidikan keluarga rendah, keterbatasan sumber daya, kebiasaankebiasaan yang salah, dan sosial budaya yang berlawanan dengan nilai-nilai keperawatan sedangkan dalam hambatan perawat terdiri dari sarana prasarana yang tidak menunjang, kondisi alam, kesulitan komunikasi, dan keterbatasan pengetahuan perawat tentang kultur keluarga. Dalam hambatan-hambatan ini seorang perawat tidak menjadikan alasan tidak melakukan proses keperawatan pada keluarga. Untuk itu proses keperawatan baik itu individu, keluarga, kelompok, dan masyarakat harus dilakukan untuk menunjang kesehatan yang lebih optimal.

\section{PENUTUP}

Keluarga merupakan unit terkecil dalam masyarakat yang merupakan entry point dalam upaya mencapai kesehatan masyarakat secara optimal. Untuk itu, dalam memberikan pelayanan kesehatan maka perlu melewati tahapan proses keperawatan. Proses keperawatan merupakan suatu proses yang kompleks dan bersifat dinamis dengan menggunakan pendekatan yang 
sistematis pada keluarga dan anggota keluarga dengan metode ilmiah.

Dalam hal ini proses keperawatan pada keluarga sudah diterapkan dan dilaksanakan atau dilakukan. Penerapan proses keperawatan ini bukan hanya pada keluarga tapi pada setiap kondisi atau keluhan yang dialami oleh pasien/klien.

Walaupun pada dasar peningkatan dalam pelayanan kesehatan keluarga masih kurang disebabkan karena kurangnya fasilitas alat-alat kesehatan yang digunakan untuk menunjang pelayanan kesehatan yang lebih baik. Dalam hal ini diperlukan dukungan pemerintah dan masyakarat dalam mewujudkan pelayanan kesehatan menjadi lebih baik dan lebih maju.

\section{REFERENSI}

Achjar, Komang Ayu H. 2012. Aplikasi Praktis Asuhan Keperawatan Keluarga. Denpasar: Sagung Seto.

Agrina, Zulfitri R. 2012. Efektifitas Asuhan Keperawatan Keluarga Terhadap Tingkat Kemandirian Keluarga Mengatasi Masalah Kesehatan di Keluarga. Jurnal Keperawatan Indonesia, 81-84.
Ali, H. Zaidin. 2009. Pengantar Keperawatan Keluarga. Jakarta: EGC. Andarmoyo, S. 2012. Keperawatan Keluarga: Konsep Teori, Proses, dan Praktik Keperawatan. Yogyakarta: Graha Ilmu.

Dion, Y., Yasinta B. 2015. Asuhan Keperawatan Keluarga Konsep dan Praktik. Yogyakarta: Nuha Media.

Febrianti, Ida. 2014. Pengaruh Penerapan Asuhan Keperawatan Keluarga Terhadap Tingkat Kemandirian Keluarga Dalam Perawatan Kesehatan Anggota Keluarga Pada Lansia. Jurnal Keperawatan Indonesia, 61-70.

Friedman, M. 2010. Buku Ajar Keperawatan Keluarga Riset, Teori, dan Praktek. Jakarta: EGC.

Harlinawati. 2013. Konsep dan Proses Keperawatan Keluarga. Sulawesi: Pustaka As Salam.

Harmoko. 2012. Asuhan Keperawatan Keluarga. Yogyakarta: Pustaka Pelajar.

Hidayat, A. Aziz Alimul. 2008. Pengantar Konsep Dasar Keperawatan. Jakarta: Salemba Medika.

Jhonson L \& Leny R. 2017. Keperawatan Keluarga Plus Contoh 
Askep Keluarga. Yogyakarta: Nuha Media.

Setiawati, S., Agus Citra D. 2008. Penuntun Praktis Asuhan Keperawatan Keluarga. Jakarta: Trans Info Media.

Simamora, R. H. (2019). Menjadi Perawat yang: CIH'HUY. Surakarta: Kekata Publisher

Suprajitno. 2004. Asuhan Keperawatan Keluarga: Aplikasi Dalam Praktik. Jakarta: EGC.

Widagdo, Wahyu. 2016. Keperawatan Keluarga dan Komunitas. Jakarta: Pusdik SDM Kesehatan.

Zendrato, S. A. (2019, September 28). Pentingnya Berpikir Kritis Untuk Menerapkan Proses Keperawatan. osf. io. 